\title{
Mounding alters environmental filters that drive plant community development in a novel grassland
}

\author{
Nate Hough-Snee* , A. Lexine Long ${ }^{1}$, Lacey Jeroue, Kern Ewing \\ University of Washington Center for Urban Horticulture and School of Forest Resources, Box 352100 Seattle, WA 98195-2100, United States
}

\section{A R T I C L E I N F O}

\section{Article history:}

Received 30 January 2011

Received in revised form 3 May 2011

Accepted 17 June 2011

Available online $\mathrm{xxx}$

\section{Keywords:}

Assembly rules

Grasslands

Indicator species

Landfill retirement

Microtopography

Novel ecosystems

\begin{abstract}
A B S T R A C T
Earthen mounds are commonly used in ecological restoration to increase environmental heterogeneity, create favorable microclimates and retain soil resources that promote plant establishment. Although mounding is commonly employed in restoration, few microtopography studies focus on the long-term effects of mounding on restored plant community development. We assessed the vegetation and physical environment of earthen mounds installed at a novel grassland ten years after restoration to look for patterns in plant community development. We used permutational multiple analysis of variance (PERMANOVA) to identify differences in plant community composition and the associated mound-driven environmental variables, summer soil moisture and height above peak soil inundation, in relation to mound position. We used indicator species analysis (ISA) to classify the species that defined mound top and intermound space plant communities. We found that mound position drove plot height above flooding and soil moisture while plant community composition was driven by plot height above flooding, summer soil moisture, and mound position. ISA showed that species colonized mound microsites differently: most wetland species occurred between mounds and xeric stress tolerators largely occupied dry mound tops. We visualized these differences with non-metric multidimensional scaling (NMDS) ordination, finding that species sorted out in multivariate space based on mound position. We conclude that mounding can have relatively long-term effects on plant community development, even in highly disturbed, minimally maintained restoration projects.
\end{abstract}

(c) 2011 Elsevier B.V. All rights reserved.

\section{Introduction}

Earthen mounds create diverse microtopography that affect soil moisture, light availability and nutrient cycling that can drive vegetation establishment and survival in a variety of ecosystems (Bruland and Richardson, 2005; Ewing, 2002a; Moser et al., 2007; Werner and Zedler, 2002). Accordingly, mounding is commonly employed within restoration projects to emulate natural microtopographic features and alter the availability of resources that may allow diverse vegetation to establish (Ewing, 2002a; Rossell et al., 2009; Simmons et al., 2011; Whisenant, 1998). Mounding has been shown to increase the establishment, survival, and diversity of seeded and planted vegetation on landfill caps (Biederman and Whisenant, 2011; Ewing, 2002a), increase plant

\footnotetext{
* Corresponding author. Present address: Utah State University Ecology Center and Watershed Sciences Department, 5210 Old Main Hill, Logan, UT 84322-5210 Unites States.

E-mail addresses: nwhs@uw.edu, natehoughsnee@gmail.com (N. Hough-Snee).

1 Present address: King County Noxious Weeds Program, 201 South Jackson Street, Seattle, WA 98104, United States.
}

species richness in restored wetlands (Bruland and Richardson, 2005; Moser et al., 2007) and drive plant community development in passively restored and planted wetlands (Rossell et al., 2009; Simmons et al., 2011) shortly after restoration. The decline of microtopography-forming tussocks in sedge meadows has been correlated to declines in native plant abundance (Werner and Zedler, 2002) while microtopographic variability has also been correlated to plant community composition in novel roadside ecosystems (Karim and Mallik, 2008) and seed bank development on grazed ski runs (Isselin-Nondedeu and Bédécarrats, 2007). While mounding is widely used in restoration and has shown very clear short-term effects on vegetation establishment, very few studies have examined how the effects of mounding may persist over longer timeframes in restored sites at the plant community level.

To see how mounding affected plant community development 10 years after restoration, we assessed plant community composition and environmental filters at a restored novel grassland ecosystem that used created microtopography to facilitate plant colonization and survival. This study had three primary objectives: (1) to estimate how the environmental filters of soil flooding and drying changed across mounds in the restored environment, (2) to 
Table 1

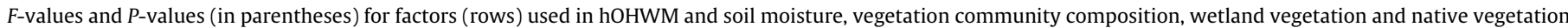
PERMANOVA analyses.

\begin{tabular}{|c|c|c|c|c|c|c|}
\hline & & \multicolumn{5}{|c|}{ Hypothesis and dependent variables from PERMANOVA models } \\
\hline & & $\begin{array}{l}\text { Hypothesis } 1 \text { : } \\
\text { mound height } \\
\text { above OHWM }\end{array}$ & $\begin{array}{l}\text { Hypothesis 2: } \\
\text { soil moisture }\end{array}$ & $\begin{array}{l}\text { Hypothesis 3a: } \\
\text { community } \\
\text { composition }\end{array}$ & $\begin{array}{l}\text { Hypothesis } 3 \mathrm{~b} \text { : } \\
\text { percent wetland } \\
\text { vegetation }\end{array}$ & $\begin{array}{l}\text { Hypothesis 3c: } \\
\text { percent native } \\
\text { vegetation }\end{array}$ \\
\hline \multirow{7}{*}{$\begin{array}{l}\text { Independent } \\
\text { variables from } \\
\text { PERMANOVA } \\
\text { models }\end{array}$} & Mound position & $17.854(0.0001)^{*}$ & $15.17(0.0001)^{*}$ & $20.16(0.0001)^{*}$ & $21.29(0.0001)^{*}$ & $6.484(0.0132)^{*}$ \\
\hline & Aspect & - & $0.13(0.7759)$ & $0.32(0.9729)$ & $0.10(0.9331)$ & $.019(0.9857)$ \\
\hline & Soil moisture & - & - & $2.68(0.0169)^{*}$ & $0.66(0.5138)$ & $2.530(0.2052)$ \\
\hline & Mound height above OHWM & - & - & $7.01(0.0001)^{*}$ & $2.03(0.1390)$ & $.143(0.7872)$ \\
\hline & $\mathrm{OHWM} \times$ mound position & - & - & $4.13(0.0022)^{*}$ & $1.33(0.3629)$ & $1.663(0.1530)$ \\
\hline & Soil moisture $\times$ mound position & - & - & $1.46(0.1109)$ & $1.25(0.1925)$ & $.359(0.6185)$ \\
\hline & Block & - & - & $3.49(0.0001)^{*}$ & $4.4(0.001)^{*}$ & $2.178(0.140)$ \\
\hline
\end{tabular}

$P<0.05$.

assess differences in plant community composition in response to mound position and environmental variables and (3) to define indicator plant species based on their mound position using indicator species analysis.

We hypothesized that mounding altered environmental filters (depth to flooding, soil moisture) and shifted the resulting vegetation communities towards species able to tolerate environmental stress and acquire limiting resources based on their position on created mounds and individual plant species growth strategies (Ewing, 2002a,b; Hough-Snee et al., 2011). Specifically, we hypothesized that the average height above the ordinary high water mark differed between mound tops and intermound spaces (1a), the effects of mound position (top or intermound) and aspect (north or south facing) drive summer soil moisture (1b) and that the effects of mound position, aspect, soil moisture, and hOHWM drive plant community composition (2a), the proportion of wetland species (2b) and the proportion of native species (2c). We chose to use wetland plant species classification as an indicator of environmental conditions. We assessed native plant abundance to see if either the mound or intermound plant communities were more native dominated. We predicted that mound topography filters vegetation by modifying the physical environment: flood-tolerant wetland species, both native and non-native, would be most abundant in the wet intermound spaces while drought-tolerant, native graminoids and forbs would dominate resource depauperate mound tops.

\section{Site history}

The site we assessed is the former E-5 parking lot on the Union Bay Natural Area (herein UBNA; Seattle, WA), a 30-Ha former landfill that was capped with clay and gravel, graded and seeded with non-native pasture grasses in 1971. The UBNA consists of several grassland and wetland ecotones, most of which suffer from several limitations to natural, native plant colonization, including low soil nitrogen and organic matter (Ewing, 2002b), low summer soil moisture (Ewing, 2002b) and abundant invasive species in areas with high levels of soil resources (Ewing, 2002b; Hough-Snee et al., 2011). Due to subsidence and shifting of capped landfill materials, E-5 persists as a basin that fills with water during winter rains, holding open water through early summer until the site dries out completely (Ewing, 2002a). Like many highly altered ecosystems, the UBNA has a short ecological memory-cumulative within site biological legacies and pressures from the surrounding matrix (e.g. Schaeffer, 2009)-that prevent returning the landscape to the historic palustrine wetland ecosystem that existed pre-landfill. Because non-native soils, abundant weeds, and novel hydrology compromise site ecological memory to drive vegetation across UBNA, the most common restoration goal across UBNA is to attain self-sustaining plant communities governed by autogenic processes rather than human maintenance (Whisenant, 1998).

To create a heterogenous environment more conducive to plant establishment, in 1998 the E-5 parking lot was disked and tilled, mounds were created and native prairie vegetation was installed. 108 mounds were created in the 1.5 -ha E- 5 area by piling gravel and cap material into circular features. Each mound was amended with a small amount of topsoil, and evenly planted with native prairie plants (annotated in Table 2). After initial construction, mounds ranged in height from $40-70 \mathrm{~cm}$ with base widths of $50-70 \mathrm{~cm}$. The interaction between substrate, precipitation and E-5's subsiding, mounded topography exposes plants to flooded or saturated conditions during the early part of the growing season and extremely dry conditions late in the growing season. Pasture grasses from upslope at UBNA have spread into E-5 following restoration, but with the exception of invasive Himalayan blackberry (Rubus armeniacus) removal, plots have received no maintenance since restoration.

\section{Methods}

In July 2008, we randomly selected and relocated 30 of the restored mounds. Four rectangular $1 / 2 \mathrm{~m}^{2}$ plots were established on each mound, two on top of each mound and two in the adjacent intermound spaces. Plots were placed lengthwise from west to east and were stratified by aspect, for a total of 120 plots. This sampling scheme provided a treatment structure equivalent to a blocked $2 \times 2$ factorial design with two mound positions, mound top or intermound space and two aspect treatments, north or south within each block. We estimated the relative abundance of all vascular plants in each plot in the first two weeks of July 2008. Species in each plot were pooled by wetland indicator status (USFWS, 1996) and then separately for their native status in Washington State (NRCS, 2010). Plant species were considered wetland indicators if their wetland status ranged between OBL and FACW. All plants with other wetland indicator statuses were considered nonwetland plants. On July 28, 2008 we measured volumetric water content at $12 \mathrm{~cm}$ within each plot using a Hydrosense CS 620 soil moisture probe (Campbell Scientific, Logan, UT, USA).

We delineated the ordinary high water mark (OHWM; Olson and Stockdale, 2010), within E-5 to define the high point at which surface water pools during the rainy season and installed a temporary benchmark from which we measured mound height above OHWM (hOHWM). We surveyed the height of each relocated mound with a standard level and rod (Nikon AC-2s, Nikon, Westminister, CO, USA) and calculated the difference between each surveyed plot height and the surveyed OHWM benchmark to yield a single hOHWM measurement for each plot. OHWM is a strong indicator of the normal elevation at which standing water creates wetland soil properties and is used in the delineation of wetlands 


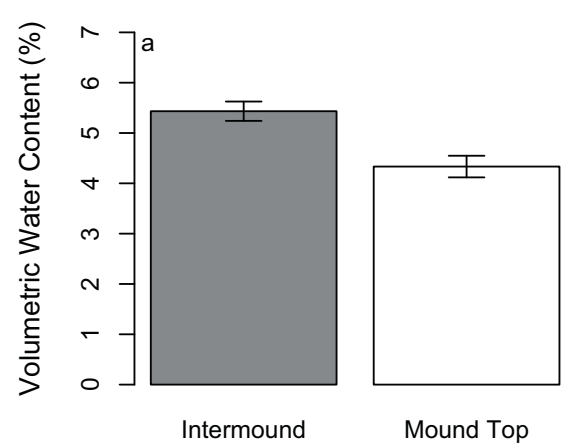

Mound Position

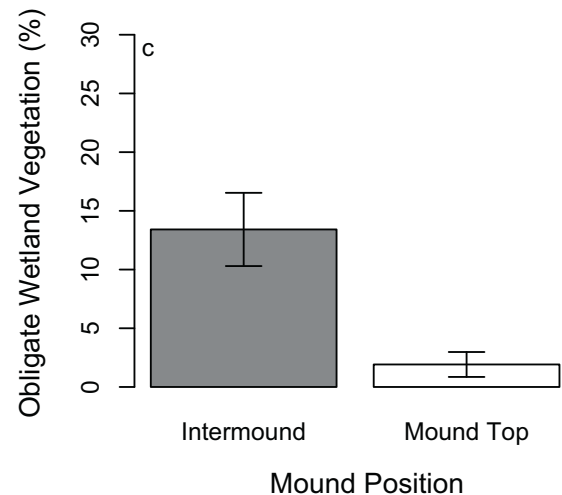

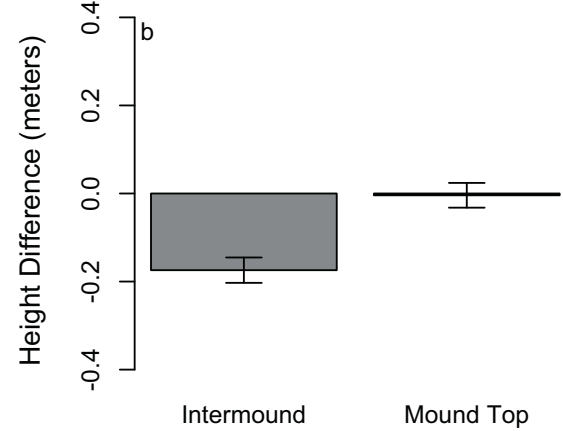

Mound Position

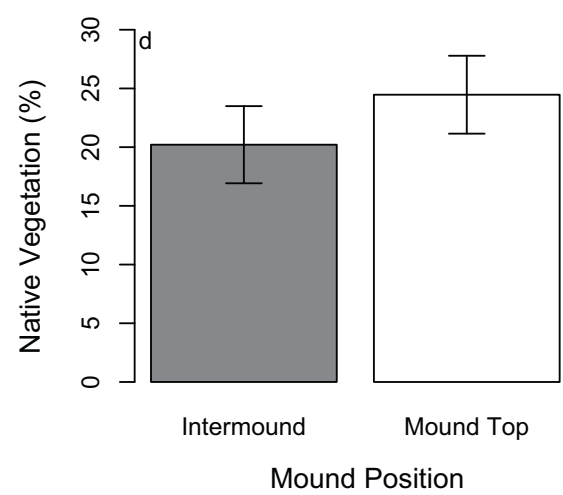

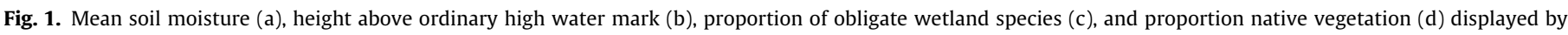

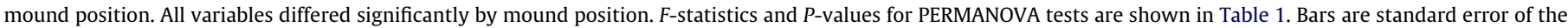
mean.

in Washington State. We used hOHWM as a proxy for the depth and duration of flooding experienced at each plot where the higher the hOHWM for a plot, the less flooding stress we considered the plant community within that plot to incur.

\section{Data analysis}

We used PERMANOVA, a permutation-based ANOVA procedure that uses pseudo $F$-tests on distance matrices to assess differences between multivariate or univariate groups (Anderson, 2001), to test our groups of hypotheses. For hypothesis $1 \mathrm{a}$, we used a one-way model with mound position as the only factor. For hypothesis $1 \mathrm{~b}$, we used a two-way model with mound position and aspect as factors. For hypotheses $2 \mathrm{a}, 2 \mathrm{~b}$ and $2 \mathrm{c}$, the full model included mound position, aspect, hOHWM, soil moisture and the interaction terms between hOHWM and mound position and between soil moisture and mound position. Block (mound) effects were included to account for additional error variability within the model (Oehlert, 2000). All PERMANOVA analyses used Bray-Curtis distance and 10,000 permutations constrained within each block (Anderson and ter Braak, 2003) to assess statistical significance. For communitylevel analyses we removed species from the data that occurred in less than 5\% of plots (McCune and Grace, 2002). We used all surveyed species to calculate the proportions of obligate wetland and native vegetation present in each plot. There were one Agrostis species and one Bromus species that could be identified only to the genus level and are referred to as Agrostis sp. and Bromus sp. in our analyses.

We visualized the vegetation community using non-metric multidimensional scaling (NMDS) and used indicator species analysis (Dufrene and Legendre, 1997) to identify species that were strongly representative of a given mound position. Indicator species analysis (ISA) serves to illustrate unique species within groups as a product of the relative abundance and relative frequency of a given species within a given group (Dufrene and Legendre, 1997; Bakker, 2008). ISA provides an indicator value of 0-100 for each species, with a perfect indicator value being 100 and a non-indicator being close to zero. Species whose indicator value for a given mound position yielded a $P$-value $<0.05$ when compared to 10,000 Monte Carlo randomizations of the full data set were considered significant indicators. All analyses were performed in the $R$ statistical package version 2.11.1 (R Development Core Team, 2010).

\section{Results and discussion}

Position on a given mound-mound top or intermound-drove both vegetation and soil moisture parameters (Table 1 ). The mean summer soil moisture for intermound plots was 5.4\% (range $=5-9 \%$ ) while mean soil moisture on the higher mound top plots was $4.1 \%$ (range $=3-8 \%, P=0.0004$; Fig. 1 ). This trend was consistent with the average hOHWM by mound position, $-0.004 \mathrm{~m}$ on the mound tops (range $=-0.35$ to $-0.71 \mathrm{~m}$ ) and $-0.174 \mathrm{~m}$ (range $=-0.51$ to $-0.66 \mathrm{~m})$ on the intermound plots $(P<0.0001$; Fig. 1$)$.

Mound and intermound vegetation communities were comprised of 67 vascular plant species and differed by mound position $(P=0.0001)$ while soil moisture and hOHWM also had significant effects (Table 1). Post hoc PERMANOVA comparisons between groups showed that the plant composition of mound tops differed from intermound plots regardless of aspect $(P<0.0001$ for all comparisons). The intermound spaces yielded higher proportions of wetland plant species (14\%) than the mound tops $(1.9 \%$; 
Table 2

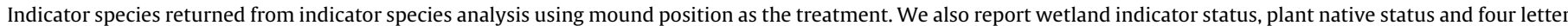

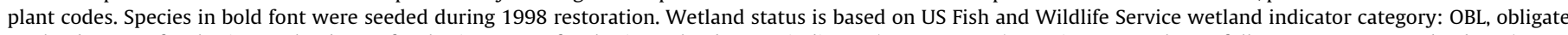

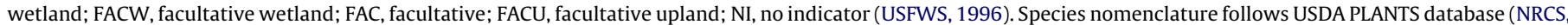
2010).

\begin{tabular}{|c|c|c|c|c|c|c|c|}
\hline Plant species & Species code & Treatment & $\begin{array}{l}\text { Indicator } \\
\text { value }\end{array}$ & Probability & $\begin{array}{l}\text { Wetland } \\
\text { status }\end{array}$ & Native status & $\begin{array}{l}\text { Plant } \\
\text { functional type }\end{array}$ \\
\hline Daucus carota & DACA & Mound & 71.05 & $0.0001^{*}$ & UPL & Non-native & Forb \\
\hline Trifolium dubium & TRDU & Mound & 52.55 & $0.0001^{*}$ & UPL & Non-native & Forb \\
\hline Vicia sativa & VISP & Mound & 39.15 & $0.0001^{*}$ & UPL & Non-native & Forb \\
\hline Holcus lanatus & HOLA & Mound & 35.39 & 0.6905 & FAC & Non-native & Graminoid \\
\hline Potentilla gracilis & POGR & Mound & 33.86 & $0.0008^{*}$ & FAC & Native & Forb \\
\hline Plantago lanceolata & PLLA & Mound & 32.67 & $0.001^{*}$ & FAC & Non-native & Forb \\
\hline Fragaria virginiana & FRVI & Mound & 27.92 & $0.0177^{*}$ & FACU & Native & Forb \\
\hline Festuca bromoides & FEBR & Mound & 25 & $0.0005^{*}$ & $\mathrm{NI}$ & Non-native & Graminoid \\
\hline Festuca idahoensis var. roemeri & FEID & Mound & 20.41 & $0.0258^{*}$ & FACU & Native & Graminoid \\
\hline Symphoricarpos alba & SYAL & Mound & 16.67 & $0.0018^{*}$ & FACU & Native & Shrub \\
\hline Festuca rubra & FERU & Mound & 16.19 & $0.0062^{*}$ & $\mathrm{FAC}+$ & Non-native & Graminoid \\
\hline Anthoxanthum odoratum & ANOD & Mound & 14.55 & 0.9298 & FACU & Non-native & Graminoid \\
\hline Juncus bufonius & JUBU & Mound & 14.24 & $0.0091^{*}$ & FACW & Native & Graminoid \\
\hline Hypericum perforatum & HYPE & Mound & 10.73 & 0.113 & UPL & Non-native & Forb \\
\hline Bromus mollis & BRMO2 & Mound & 10.37 & 0.0746 & UPL & Non-native & Graminoid \\
\hline Bromus spp. & BRSP & Mound & 8.87 & 0.1084 & $\mathrm{NI}$ & Non-native & Graminoid \\
\hline Rubus armeniacus & RUAR & Mound & 6.67 & 0.7111 & FACU & Non-native & Shrub \\
\hline Populus balsamifera & POBAT & Mound & 6.04 & 0.6339 & FAC & Native & Tree \\
\hline Hypochaeris radicata & HYRA & Mound & 4.24 & 0.6948 & FACU & Non-native & Forb \\
\hline Phalaris arundinacea & PHAR & Mound & 3.08 & 1.00 & FACW & Non-native & Graminoid \\
\hline Agrostis stolonifera & AGST & Intermound & 44.72 & $0.0001^{*}$ & FAC & Non-native & Graminoid \\
\hline Schedonorus pratensis & SCPR & Intermound & 35.27 & $0.0026^{*}$ & FACU & Non-native & Graminoid \\
\hline Agrostis tenuis & AGTE & Intermound & 34.39 & $0.0093^{*}$ & FAC & Non-native & Graminoid \\
\hline Eleocharis palustris & ELPA & Intermound & 30.64 & $0.0004^{*}$ & $\mathrm{OBL}$ & Native & Graminoid \\
\hline Trifolium pratense & TRPR & Intermound & 24.52 & $0.0088^{*}$ & UPL & Non-native & Forb \\
\hline Lotus corniculatus & LOCO & Intermound & 21.33 & $0.0036^{*}$ & FAC & Non-native & Forb \\
\hline Melilotus alba & MEAL & Intermound & 13.33 & $0.0071^{*}$ & FACU & Non-native & Forb \\
\hline Cichorium intybus & CIIN & Intermound & 13.23 & 0.3418 & UPL & Non-native & Forb \\
\hline Agrostis spp. & AGSP & Intermound & 10.17 & 0.3555 & NI & Non-native & Graminoid \\
\hline Juncus accuminatus & JUAC & Intermound & 10.00 & $0.0289^{*}$ & OBL & Native & Graminoid \\
\hline Achilea millefolium & ACMI & Intermound & 8.12 & 0.5525 & FACU & Native & Forb \\
\hline Lythrum salicaria & LYSA & Intermound & 8.08 & 0.2762 & FACW & Non-native & Forb \\
\hline Leucanthemum vulgare & LEVU & Intermound & 8.00 & 0.2463 & NI & Non-native & Forb \\
\hline Parentucellia viscosa & PAVI & Intermound & 5.33 & 0.4802 & FAC- & Non-native & Forb \\
\hline
\end{tabular}

* Species that were statistically significant indicators (10,000 permutations).

$P=0.001$ for mound position). Mound tops showed a higher mean proportion of native vegetation (24.5\%) than the intermound spaces (20.2\%; $P=0.013$ for mound position). NMDS ordination returned a three dimensional solution with a stress of $13.73(P=0.0099,10,000$ permutations) and an $R^{2}$ of 0.915 (Fig. 2). There were 24 species that significantly affected the ordination results $(P<0.05)$ and both plots and species appeared to sort by mound position and hOHWM (NMDS axis 1 ; Fig. 2 ).

ISA returned 11 and 8 statistically significant indicator species for mound tops and intermounds respectively (Table 2). The strongest indicator species for the intermound treatment were either facultative or obligate wetland graminoids whereas the mound top indicator species were largely upland forb species. The strongest native indicator species for mound tops included Festuca idahoensis var. roemeri, Fragaria virginiana and Potentilla gracilis, all species adapted to drought stress and considered stress tolerators. We anticipated that these native species would compete with weedy forbs that exploit soil resources, but this did not occur: the strongest overall mound top indicators were non-native forbs-Daucus carota, Trifolium dubium and Vicia sativa-with large taproots that may enhance resource acquisition. Eleocharis palustris, a flood-tolerant, native wetland species, and the non-native facultative species Agrostis stolonifera and Schedonorus pratensis thrived in the more deeply flooded intermound spaces. The strongest intermound indicators-A. stolonifera, S. pratensis and Agrostis tenuis-were all graminoids with plastic tolerances to both flooding and drying. The observed indicator species suggest that

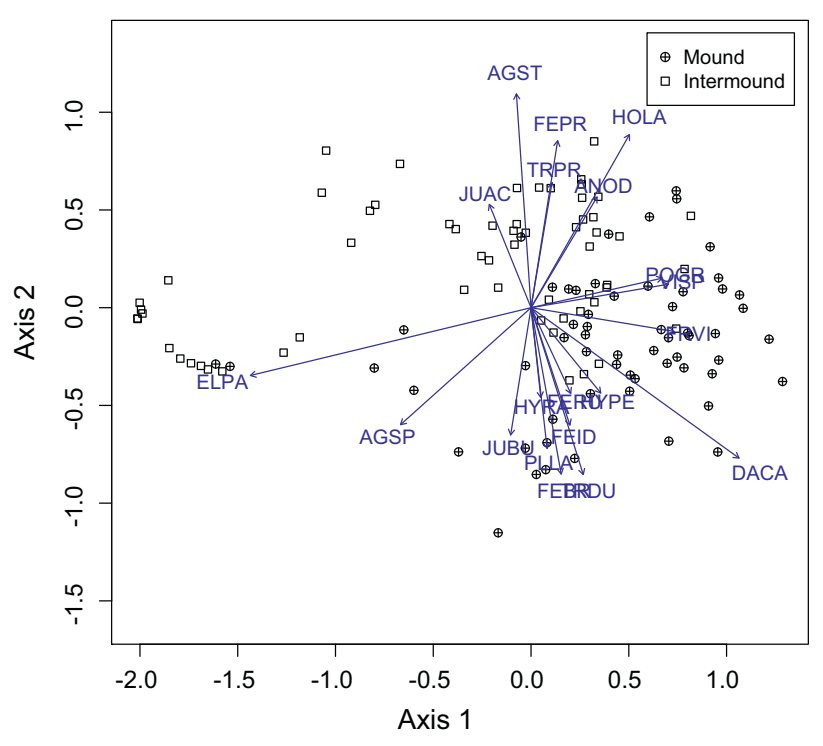

Fig. 2. The first two axes from the NMDS ordination for the vegetation community show a distinct grouping between the plant communities encountered on the tops of mounds and the adjacent intermound spaces. Species loading vectors with a $P$-value $<0.01$ ( 10,000 permutations) are plotted over sites although we found 24 significant species at $P=0.05$. Four letter species codes correspond to those used in Table II. NMDS stress $=13.7303$ and linear $R^{2}=0.912$. 
plant success on and around microtopography is a product of species' ability to endure flooding or drought that drive distinct assemblages by mound position and total onsite plant diversity.

\section{Conclusions}

Mounding facilitated distinct differences in environmental filters and plant functional diversity ten years after restoration of a former parking lot to grassland. Both mound positions experience dry summer soils and are at least partially inundated in winter, but the drier, higher mound tops exhibited higher average hOHWM and lower summer soil moisture that filtered the plant community towards more native, drought-tolerant forbs and graminoids and less flood-tolerant wetland species than the intermound areas. These long-term results are supported by studies that document the short-term effects of mounding on the success of planted and seeded grassland and forest vegetation (Biederman and Whisenant, 2011; Ewing, 2002a; Simmons et al., 2011) and wetland vegetation recovery following disturbance (Anderson et al., 2007; Vivian-Smith, 1997). Our results also corroborate observations that decreased soil moisture and higher microtopographic elevations correlate to increased stress-tolerating, native plant composition in other novel plant communities (Karim and Mallik, 2008).

While achieving high levels of plant functional and species diversity are common goals in reclamation and ecosystem restoration projects (Biederman and Whisenant, 2011; Zedler, 2005), site modification should be paired with adaptive vegetation management to direct full autogenic recovery of a given site. Restoration practitioners attempting to create diverse plant communities on resource-poor sites should consider engineered mounds to increase site environmental heterogeneity that provides diverse niches for plants (Vivian-Smith, 1997). Mounding facilitates long-term changes in a site's physical performance, but does not necessarily increase native species composition or yield desirable successional trajectories without further management (Whisenant, 1998). For example, in reclamation projects, landform often interacts with plant species' growth form and life strategy over relatively long timeframes to drive plant communities (Jochimsen, 2001, Rudgren et al., 2011), regardless of initial propagule introduction or soil amendment that may drive vegetation in short (Ewing, 2002b) or long timeframes (Conrad and Tischew, 2011; Hough-Snee et al., 2011). When a project objective is to increase native plant biodiversity over long timeframes rather than to create a self-sustaining novel plant community, practitioners should pair the creation of microtopographic features with invasive species management and consider introducing supplemental propagules of native plant species whose performance matches created microsites allowing them to outcompete resource efficient invasive species.

\section{Acknowledgements}

We thank Jon Bakker for feedback during project formulation, Wendy Descamp and the University of Washington Douglas Hyde Herbarium for assistance in confirming the identities of plant species found on-site and Kurt Zogorski and Derrick Cooper for field assistance. We are also grateful to Joy Zedler, Liam Stacey, Rodney Pond, Bill Mitsch and two anonymous reviewers for providing useful feedback on early drafts of this manuscript.

\section{References}

Anderson, M.J., 2001. A new method for non-parametric multivariate analysis of variance. Aust. Ecol. 26, 32-46.

Anderson, M.J., ter Braak, C.J.F., 2003. Permutation tests for multi-factorial analysis of variance. J. Stat. Comput. Simul. 73, 85-113.

Anderson, H.M., Gale, M.R., Jurgensen, M.F., Trettin, C.C., 2007. Vascular and nonvascular plant community response to silvicultural practices and resultant microtopography creation in a forested wetland. Wetlands 27, 68-79.

Bakker, J.D., 2008. Increasing the utility of indicator species analysis. J. Appl. Ecol. $45,1829-1835$.

Biederman, L.A., Whisenant, S.G., 2011. Using mounds to create microtopography alters plant community development early in restoration. Restor. Ecol. 19, 53-61.

Bruland, G.L., Richardson, C.J., 2005. Hydrologic, edaphic, and vegetative responses to microtopographic reestablishment in a restored wetland. Restor. Ecol. 13, 515-523.

Conrad, M.K., Tischew, S., 2011. Grassland restoration in practice: do we achieve the targets? a case study from Saxony-Anhlat/Germany. Ecol. Eng. 37, 1149-1157.

Dufrene, M., Legendre, P., 1997. Species assemblages and indicator species: the need for a flexible asymmetrical approach. Ecol. Monogr. 67, 345-366.

Ewing, K., 2002a. Mounding as a technique for restoration of prairie on a capped landfill in the Puget Sound lowlands. Restor. Ecol. 10, 289-296.

Ewing, K., 2002b. Effects of initial site treatments on early growth and three-year survival of Idaho fescue. Restor. Ecol. 10, 282-288.

Hough-Snee, N., Bakker, J.D., Ewing, K., 2011. Long-term effects of initial site treatment on fescue in a novel prairie ecosystem (Washington). Ecol. Restor. 29, 14-17.

Isselin-Nondedeu, F., Bédécarrats, A., 2007. Soil microtopographies shaped by plants and cattle facilitate seed bank formation on alpine ski trails. Ecol. Eng. 30, 278-285.

Jochimsen, M.E., 2001. Vegetation development and species assemblages in a longterm reclamation project on mine spoil. Ecol. Eng. 17, 187-198.

Karim, M.N., Mallik, A.U., 2008. Roadside revegetation by native plants I. Roadside microhabitats, floristic zonation and species traits. Ecol. Eng. 32, 222-237.

McCune, B., Grace, J.B., 2002. Analysis of Ecological Communities. MjM Software Design, Gleneden Beach, OR.

Moser, K., Ahn, C., Noe, G., 2007. Characterization of microtopography and its influence on vegetation patterns in created wetlands. Wetlands 27, 1081-1097.

United States Department of Agriculture (USDA), NRCS. 2010. The PLANTS Database. National Plant Data Center, Baton Rouge, LA 70874-4490, USA. http://plants.usda.gov.

Oehlert, G. W., 2000. A first course in design and analysis of experiments. WH Freeman, New York, New York, USA. 600 p.

Olson, P., Stockdale, E., 2010. Determining the Ordinary High Water Mark on Streams in Washington State. Second Review Draft. Washington State Department of Ecology, Shorelands \& Environmental Assistance Program, Lacey, WA. Ecology Publication \# 08-06-001.

R Development Core Team, 2010. R: A language and environment for statistical computing. R Foundation for Statistical Computing, Vienna, Austria, ISBN 3900051-07-0, http://www.R-project.org.

Rossell, I.M., Moorhead, K.K., Alvarado, H., Warren, R.J., 2009. Succession of a southern Appalachian mountain wetland six years following hydrologic and microtopographic restoration. Restor. Ecol. 17, 205-214.

Rudgren, K., Halvorsen, R., Odland, A., Skjerdal, G., 2011. Restoration of Alpine spoil heaps: successional rates predict vegetation recovery in 50 years. Ecol. Eng. 37, 294-301.

Schaeffer, V., 2009. Alien invasions, ecological restoration in cities and the loss of ecological memory. Restor. Ecol. 17, 171-176.

Simmons, M.E., Ben Wu, X., Whisenant, S.G., 2011. Plant and soil responses to created microtopography and soil treatments in bottomland hardwood forest restoration. Restor. Ecol. 19, 136-146.

United States Fish and Wildlife Service (USFWS). 1996. National list of vascular plant species that occur in wetlands: 1996 national summary-indicator by region and subregion. http://library.fws.gov/Pubs9/wetlands_plantlist96.pdf.

Vivian-Smith, G., 1997. Microtopographic heterogeneity and floristic diversity in experimental wetland communities. J. Ecol. 85, 71-82.

Werner, K.J., Zedler, J.B., 2002. How sedge meadow soils, microtopography, and vegetation respond to sedimentation. Wetlands 22, 451-466.

Whisenant, S.G., 1998. Restoring Degraded Wildlands: A Process-Orientated Approach. Cambridge University Press.

Zedler, J.B., 2005. Restoring wetland plant diversity: a comparison of existing and adaptive approaches. Wetl. Ecol. Manag. 13, 5-14. 